\title{
JPH Editor's Note
}

The Los Angeles riots that occurred in May 1992 catapulted the problems of the city back on the policy agenda. The cauldron of social problems of the city, as the the riots showed, offers no simple solutions. Indeed, urban policy includes a range of policy issues involving welfare, housing, job training, education, drug control, and the environment. The myriad local, state, and federal agencies only further complicate formulating and implementing coherent policies for the city.

This volume, while not offering specific proposals to remedy the problems of the city, provides a broad historical context for discussing contemporary urban policy. The essays address issues related to public housing, poverty, transportation, and the environment. In doing so, the authors discuss larger themes in urban policy as well as provide case studies of how policies have been implemented over time in specific cities. Of particular interest, two of the essays discuss the role of the historian in shaping urban policy and the importance of historical preservation in urban planning.

This volume therefore provides a context for looking at urban policy in different ways and for arriving at new prescriptions for relieving the ills of the American city. 